\title{
In vivo pulmonary metastatic profile of breast cancer cell lines expressing hormonal receptors versus triple negative
}

\author{
M João Carvalho ${ }^{1,2,3 *}$, A Margarida Abrantes ${ }^{2,3}$, Mafalda Laranjo ${ }^{2,3}$, Francisco Falcão', Sofia Cabrita ${ }^{4}$, \\ M Filomena Botelho ${ }^{1}$, Carlos F de Oliveira ${ }^{3}$, Isabel Torgal ${ }^{1}$ \\ From 16th International Charles Heidelberger Symposium on Cancer Research \\ Coimbra, Portugal. 26-28 September 2010
}

Breast cancer metastized to lungs is a challenge considering clinical management and molecular processes. The interaction between tumor cells and lung environment as well as the influence of hormonal receptor (HR) are a question of debate.

The aim of this study is the characterization of pulmonary metastatic spread in vivo of breast cancer cell lines that express HR comparing with triple negative (TN) after injection in the tail vein.

It was performed injection in the tail vein of female mice Balb/c nude with $1.5 \times 10^{6}$ cells of each breast cancer cell line (MCF7 and HCC1806) previously labeled with ${ }^{99 \mathrm{~m}} \mathrm{Tc}$-HMPAO. Imagiological studies with ${ }^{99 \mathrm{~m}} \mathrm{Tc}$ HMDP and ${ }^{99 m}$ Tc-MIBI were performed between $7^{\text {th }}$ and $8^{\text {th }}$ weeks and then sacrificed. The lungs were submitted to histological image analysis focusing on regions of interest (ROI), in order to obtain lesion areas.

Tumor cells injected labeled with ${ }^{99} \mathrm{~m}$ Tc-HMPAO showed a preference embolization to the lungs. The ROI analysis of imagiological studies with ${ }^{99 m}$ Tc-HMDP and ${ }^{99 \mathrm{~m}}$ Tc- MIBI did not reveal significant differences according to each cell type. Histology showed metastatic lung foci in all animals injected. On one hand, the number of lung foci was not significantly different considering MCF7 and HCC1806 injection. On the other hand, the mean area of lung metastasis in MCF7 cases were significantly higher than in HCC1806 ( $p=0.023$ ).

The mice injected with HR positive breast cancer cells in the tail vein were associated with higher lung metastatic areas than TN cells. This emphasizes the influence

* Correspondence: mariaj.carvalho@sapo.pt

'Gynaecology Service, University Hospitals of Coimbra, Coimbra, Portugal Full list of author information is available at the end of the article of HR in the expression of growth factors and pulmonary neovascularization that is not still delineated.

\section{Author details}

${ }^{1}$ Gynaecology Service, University Hospitals of Coimbra, Coimbra, Portugal. ${ }^{2}$ Biophysics/Biomathematics Institute, IBILI, Faculty of Medicine, University of Coimbra, Coimbra, Portugal. ${ }^{3} \mathrm{CIMAGO}$, Faculty of Medicine, University of Coimbra, Coimbra, Portugal. ${ }^{4}$ Experimental Pathology Institute, Faculty of Medicine, University of Coimbra, Coimbra, Portugal.

Published: 24 September 2010

\section{doi:}

Cite this article as: Carvalho et al:: In vivo pulmonary metastatic profile of breast cancer cell lines expressing hormonal receptors versus triple negative. BMC Proceedings 2010 4(Suppl 2):P43.
Submit your next manuscript to BioMed Central and take full advantage of:

- Convenient online submission

- Thorough peer review

- No space constraints or color figure charges

- Immediate publication on acceptance

- Inclusion in PubMed, CAS, Scopus and Google Scholar

- Research which is freely available for redistribution

Submit your manuscript at www.biomedcentral.com/submit
Biomed Central 